\title{
A VONTADE GERAL COMO PROCESSO ÉTICO- JURÍDICO DE DELIBERAÇÃO COLETIVA E MOVIMENTO ECONÔMICO-POLÍTICO DE INSTITUCIONALIZAÇÃO DO PODER
}

\author{
Luiz Carlos Mariano da Rosa \\ Graduado em Filosofia pelo Centro Universitário Claretiano \\ de Batatais (Ceuclar/SP) e pós-graduado em Filosofia pela \\ Universidade Gama Filho (UGF/RJ). Professor-pesquisador \\ e filósofo-educador no Espaço Politikón Zôon - Educação, \\ Arte e Cultura.marianodarosaletras@outlook.com
}

Resumo

Baseado na perspectiva rousseauniana, que confere à Vontade Geral a condição para o exercício da soberania popular, o artigo em questão, a partir da concepção dialético-materialista da universalidade, detém-se em seu processo de formação que, inter-relacionando deliberação e decisão, tende à correspondência entre fato e direito, convergindo para assinalar a sua capacidade de atribuir ao sistema de direitos e deveres a necessária conformidade envolvendo a realidade histórico-cultural e econômico-social concreta. Dessa forma, implicando a realização do Direito por meio do exercício do poder, à instância do instituído, 0 artigo impõe a Vontade Geral como um processo ético-jurídico que envolve as decisões coletivas e, antes, a sua elaboração, mediante um movimento dialético que tende à institucionalização de valores, necessidades e fins que convergem para a universalidade concreta que cabe à Constituição e às leis.

Palavras-chave:

Poder. Direito. Estado. Rousseau. Vontade Geral.

\section{GENERAL WILL AS ETHICAL AND LEGAL PROCESS OF COLLECTIVE DELIBERATION AND ECONOMIC AND POLITICAL MOVEMENT FOR POWER INSTITUTIONALIZATION}

\section{Abstract:}

Based on Rousseau's perspective, which gives the General Will the condition for the exercise of popular sovereignty, the article in question, from the dialectical-materialist conception of universality, is arrested in its formation process that interrelating deliberation and decision tends to correspondence between fact and law, converging to mark its ability to assign the rights of system and duties required compliance involving historical-cultural reality and concrete economic and social. Thus implying the realization of the law through the exercise of power, to the instituted instance Article imposes the General Will as an ethical-legal pro- 
cess involving the collective decisions and, before their preparation, through a dialectical movement that tends to the institutionalization of values, needs and purposes that converge to the concrete universality that it is the Constitution and the laws.

\section{Keywords:}

Power. Right. State. Rousseau. General Will.

\section{Sumário}

1 Aspectos Introdutórios. 2 Da dialética essencial entre Direito e Poder na constituição do Estado e a Vontade Geral como processo ético-jurídico de deliberação coletiva e princípio de integração dinâmico-dialética. 3 Da conversão da Vontade Geral em legislação como objetivação de valores, necessidades e fins do corpo coletivo e moral. 4 Da Vontade Geral como processo ético-jurídico de decisão coletiva e forma de exercício do poder econômico-político. 5 Aspectos Conclusivos. 6 Referências. 


\section{ASPECTOS INTRODUTÓRIOS}

Quando se propóe uma lei na assembleia do povo, o que se lhes pergunta não é precisamente se aprovam ou rejeitam a proposta, mas se estão ou não de acordo com a vontade geral que é a deles; cada um, dando o seu sufrágio, dá com isso a sua opinião, e do cálculo dos votos se conclui a declaração da vontade geral (ROUSSEAU, 1999, p. 205).

Consistindo em uma espécie de padrão de orientação concernente a uma determinada proposição e a sua relação com o bem comum, a Vontade Geral emerge, subsequentemente, como resultado do processo, assumindo uma condição que não se impóe senão como a sua declaração, ${ }^{1}$ perfazendo a expressão do interesse comum e convergindo para a transposição do indivíduo das fronteiras que encerram a dependência dos homens e, consequentemente, o caráter arbitrário das suas vontades e dos seus interesses particulares, à medida que, por meio das leis, que corporificam os atos gerais, guarda possibilidade de se lhes escapar, alcançando no estado social a capacidade de correlacionar liberdade, "moralidade" e "virtude".2

Cada indivíduo, com efeito, pode, como homem, ter uma vontade particular, contrária ou diversa da vontade geral que tem como cidadão. Seu interesse particular pode ser muito diferente do interesse comum. Sua existência, ab-

1 Convém esclarecer que a teoria política de Rousseau assinala que "a declaração da vontade soberana em legislação é por meio da VONTADE GERAL, que é a única que legitima a LEI. Como súdito, cada indivíduo está subordinado a uma lei em cuja elaboração participou como membro do corpo soberano. Na opiniáo de Rousseau, nenhuma outra base da lei pode ser legítima. A lei que é proclamada por apenas alguns poucos num estado impóe servidáo àqueles que são compelidos a sujeitar-se-lhe e não lhes estabelece nenhuma obrigaçáo de obediência” (DENT, 1996, p. 90).

2 "Não seria possível pensar um rumo em direção a uma comunidade humana autêntica e verdadeira, que não necessitasse mais das molas do poder, da ganância e da vaidade, mas que estivesse fundada inteiramente na submissão comum a uma lei interiormente reconhecida como necessária e obrigatória? Logo que essa forma de comunidade surgir e se estabelecer, o mal enquanto mal social - e é só este que, como vimos, conta para Rousseau - será superado e eliminado. Se a forma coercitiva de sociedade existente até agora desmoronar e for substituída por uma forma livre de comunidade política e ética - uma forma na qual todos, em vez de estarem submetidos à arbitrariedade dos outros, reconhecem, aprovam e acatam como sua própria apenas a vontade geral -, então a hora da redenção chegou. Mas essa redenção espera em vão por ajuda exterior. Nenhum Deus nos pode enviá-la; o homem deve sim se transformar no seu próprio salvador e, no sentido ético, no seu criador" (CASSIRER, 1999, p. 74). 
soluta e naturalmente independente, pode levá-lo a considerar o que deve à causa comum como uma contribuição gratuita, cuja perda prejudicará menos aos outros, do que será oneroso o cumprimento a si próprio. Considerando a pessoa moral que constitui o Estado como um ente de razão, porquanto não é um homem, ele desfrutará dos direitos do cidadão sem querer desempenhar os deveres de súdito - injustiça cujo progresso determinaria a ruína do corpo político (ROUSSEAU, 1999, p. 75).

Se sob a acepção de uma emanação do soberano a Vontade Geral guarda uma tendência que necessariamente implica interesse comum, à medida que emerge das fronteiras que encerram o princípio que se lhe atribui a condição de infalibilidade e que envolve a noção de que não se pode desejar senão sub specie boni, o sentido que carrega como a própria decisão coletiva converge para não permitir tal caracterização, tendo em vista que neste último caso mantém dependência concernente a um juízo cuja retidão corresponde à possibilidade do conhecimento da Vontade Geral como padrão ou regra, se lhe demandando como tal.

Perfazendo o momento da formação da vontade, a deliberação ${ }^{3}$ guarda precedência em relação à decisão, convergindo para um horizonte que encerra várias perspectivas nas fronteiras das quais as preferências pessoais se movimentam, consistindo-se em uma noção que escapa à leitura rousseauniana, que se circunscreve à última etapa do processo, ${ }^{4}$ subestimando-o enquanto possibilidade de revelação

3 Para fins de esclarecimento do referido processo, cabe recorrer à reflexão de Gramsci acerca das deliberaçôes coletivas: "As deliberaçóes estabelecidas colectivamente devem apoiar-se na razão. Pode a razão ser interpretada por uma colectividade? Decerto que o único consegue deliberar mais depressa (para encontrar a razão, a verdade) do que uma colectividade. Porque o único pode ser escolhido entre os mais capazes, entre os mais bem preparados para interpretar a razáo, enquanto a colectividade é composta por elementos diversos, preparados em diversos graus, para compreender a verdade, para desenvolver a lógica de uma finalidade, para fixar os diversos momentos através dos quais é preciso passar para se alcançar o próprio fim. Tudo isto é verdade, mas é também verdade que o único pode tornar-se (ou ser visto) num tirano e a disciplina por ele imposta pode desagregar-se porque a colectividade se recusa, ou não consegue compreender, a utilidade da açáo, enquanto a disciplina fixada pela própria colectividade aos seus componentes, mesmo que tarde a ser posta em prática, dificilmente falha na sua efectivação" (GRAMSCI, 1976, p. 172, grifos do autor).

4 Baseado na leitura de Bernard Manin, torna-se relevante, nessa perspectiva, a observação do estudo de Vita (1991, p. 220), que sublinha a "concepção limitada de deliberação" que caracteriza a construção de Rousseau no que tange as suas restriçôes à discussão pública, circunscrevendo-se o conceito rousseauniano às fronteiras da decisão, às quais se mantém reduzida a sua interpretação, se lhe escapando consequentemente "o processo de formação da vontade - individual ou coletiva", tendo em vista que 
da Vontade Geral, à medida que, encerrando a concepção que a mantém subjacente às consciências ${ }^{5}$ dos membros do soberano, tende a atribuir naturalidade a sua emergência.

À abstração de um direito humano em geral, que se caracteriza, pois, como a "essência" da comunidade, o que se impóe é a concreticidade da vida históricocultural e socioeconômica e a realidade das forças sociais em ação; ambas as quais, em sua gênese, traz os homens no âmbito das relaçóes que o sistema produtivo demanda, convergindo para uma construção que seja capaz de consubstanciar os valores, as necessidades e os objetivos que se lhe estão atrelados em um processo que tende a atualizar o arcabouço político-jurídico, à medida que dialoga com a superação ${ }^{6}$ do instituido e a institucionalização de um novo mundo ético.

\footnotetext{
"em seu sentido mais forte, deliberação diz respeito ao momento que precede a decisão e durante o qual o indivíduo se interroga sobre as diferentes alternativas e sobre suas próprias preferências", o que implica, pois, no momento da formação da vontade.
}

5 Alcança relevância a concepção que atribui à Vontade Geral a condição que, no tocante ao indivíduo em seu aspecto jurídico e a sua essência abstrata e extratemporal, implica uma "encarnação", visto que se mantém em estado de imanência em face da consciência, conforme a perspectiva que, baseada no pensamento de Gurvitch, Derathé sublinha, analisando a analogia que, envolvendo a Vontade Geral e a consciência, impóe-se à construção rousseauniana. Dessa forma, Derathé afirma que "a vontade geral e a consciência têm traços comuns, antes de tudo, não apenas por serem 'sempre retas' e 'indestrutíveis', mas também por poderem tornar-se mudas em cada indivíduo quando as paixôes ou os preconceitos falam mais forte do que elas" (DERATHÉ, 2009, p. 347), além de assinalar que, "se, segundo Rousseau, não é 'impossível explicar o princípio imediato da consciência pelas consequências de nossa natureza', é porque, como todo impulso natural, ela deriva em todos os homens do 'amor de si mesmo'. Ora, o mesmo ocorre com a vontade geral. Ela não pode vincular-se à nossa natureza sem derivar, por sua vez, do 'amor de si', já que este é, segundo Rousseau, 'o único motivo que faz os homens agir”' (DERATHÉ, 2009, p. 348).

6 Eis o sentido do momento da superação, segundo Henri Lefebvre: "Na superação, o que é superado é abolido, suprimido - num certo sentido. Não obstante, em outro sentido, o superado não deixa de existir, não recai no puro e simples nada; ao contrário, o superado é elevado a nível superior. E isso porque ele serviu de etapa, de mediaçáo para a obtençấo do 'resultado' superior; certamente, a etapa atravessada não mais existe em si mesma, isoladamente, como ocorria num estágio anterior (...). A superação implica, por conseguinte, um retorno ao passado: um aprofundamento do passado. Em cada etapa do desenvolvimento da natureza, da vida, do pensamento, o passado é reencontrado - mas superado e, por isso mesmo, aprofundado, liberado de suas limitaçóes, mais real que no início. Esse sentido de superação deve ser longamente meditado, até que se possa captar toda a sua profundidade" (1991, p. 230-231, grifos do autor). 
Se consiste em uma ação instituinte que se impóe por meio do movimento dialético que envolve forma e conteúdo, reprodução e produção, relaçóes e normas, a Vontade Geral converge para a institucionalização de valores, necessidades e objetivos que emergem das fronteiras que encerram a confluência entre os homens enquanto indivíduos em sua concreticidade histórico-cultural e socioeconômica e os meios de produção, a saber, a base social e a base material.'

Sobrepondo-se ao caráter vago e indefinido que se lhe atribui a leitura que tende a lhe impor a condiçáo que supóe um arcabouço existente a priori, uma estrutura sem raízes concretas como que suspensa no ar, imune ao contato histórico-cultural e socioeconômico e, antes, aos próprios homens que por intermédio das suas vontades e interesses particulares a perfazem enquanto tal, a organização político-social consiste em um sistema de atividades intencionais que não convergem senão para a construção da Vontade Coletiva. Ao substrato material, que implica a formação econômico-social e se lhe dispóe e determina, não perfazendo senão a sua "essência", o que se impóe é a correlação envolvendo as forças produtivas e as necessidades sociais, convergindo, pois, para a constituiçáo dos próprios homens, do modo específico de ser (e de fazer-se) dos homens enquanto indivíduos em sua concreticidade histórico-cultural e socioeconômica.

Nessa perspectiva, o que a Vontade Geral encerra é um processo que, no que respeita à instituição e ao seu conceito, converge para se lhe atribuir a caracterização que envolve uma concepçáo dinâmica, que se sobrepóe à noçáo que sugere uma manifestação que advém de comportamentos e modos de pensar que emergem das fronteiras de uma abstração da coletividade, ${ }^{8}$ constituindo-se, pois, como impessoais.

7 Nesta perspectiva, cabe salientar a concepção que encerra "como máximo factor de história não os factos econômicos, materiais, mas o homem, mas a sociedade dos homens, dos homens que se apoiam mutuamente, se entendem mutuamente, desenvolvem através destes contactos (civilização) uma vontade social, colectiva, compreendem os factos econômicos, julgam-nos e adequam-nos à sua vontade, até que esta se torne a força motriz da economia, e plasmadora da realidade objectiva, que vive e se move e adquire caráter de matéria telúrica em ebulição, que pode ser canalizada onde e como convenha a vontade" (GRAMSCI, 1976, p. 162).

8 "A coletividade deve ser entendida como produto de uma elaboração de vontade e pensamento coletivos, obtidos através do esforço individual concreto, e não como resultado de um processo fatal estranho aos indivíduos singulares: daí, portanto, a obrigação da disciplina interior, e não apenas daquela exterior e mecânica. Se devem existir polêmicas e cisóes, é necessário não ter medo de enfrentá-las e superá-las: elas são inevitáveis nestes processos de desenvolvimento e evitá-las significa somente adiá-las para quando já forem perigosas ou mesmo catastróficas, etc.” (GRAMSCI, 2001, p. 232). 
Tal noção implica que a sua existência escapa ao âmbito psicológico dos homens enquanto indivíduos em sua concreticidade histórico-cultural e socioeconômica, perfazendo uma herança, um "patrimônio morto", cuja forma se impóe aos seus integrantes, que somente alcançam a condição de membros por meio da coação social e da violência simbólica e real que o seu funcionamento como tal requer.

Consistindo na possibilidade de que os homens enquanto indivíduos em sua concreticidade histórico-cultural e socioeconômica, realizem a experiência que implica sua unidade em relação ao todo, a Vontade Geral, longe do exercício de uma liberdade que supóe a eliminação absoluta das restriçóes impostas as suas vontades particulares e aos seus interesses em detrimento dos demais membros do corpo coletivo e moral, converge para a construçáo da autonomia que encerra como conteúdo a intersubjetividade e o interesse comum. ${ }^{9}$ Dessa forma, pressupondo a realidade coletiva como a sua condiçáo, a Vontade Geral implica concepção de soberania (popular) não como um fenômeno estático, restrito à formalidade político-jurídica, mas como um processo cujo devir guarda a noção de poder que a determina e legitima. ${ }^{10}$

Pressuposto da organização do poder que a existência do corpo coletivo e moral implica, a Vontade Geral não guarda capacidade senão de se sobrepor à desigualdade e à injustiça que, porventura, emergem das relaçóes dos homens enquanto indivíduos em sua concreticidade histórico-cultural e socioeconômica e as unidades sociais particulares entre si, à medida que carrega a possibilidade de engendrar a correspondência devida entre fato e direito mediante processo que envolve as decisóes coletivas e, antes, a sua deliberação. Tal processo converge para

9 Sobrepondo-se à concepçấo que envolve um "composto de vontades particulares" ou um compromisso que as abrange, a Vontade Geral consiste na vontade de todo aquele que guarda, pois, a condiçâo de membro do soberano, o que implica suposição de que "os cidadáos tenham uma vontade comum, o que seria evidentemente impossível se eles estivessem divididos em tudo, se não houvesse também um interesse comum, base psicológica da associação e que, desse ponto de vista, constitui o laço entre os associados" (DERATHÉ, 2009, p. 343, grifos do autor).

10 Tendo em vista que "năo sendo o Estado ou a cidade mais que uma pessoa moral, cuja vida consiste na uniấo de seus membros, e se o mais importante de seus cuidados é o de sua própria conservaçáo, torna-se-lhe necessária uma força universal e compulsiva para mover e dispor cada parte da maneira mais conveniente a todos. Assim como a natureza dá a cada homem poder absoluto sobre todos os seus membros, o pacto social dá ao corpo político um poder absoluto sobre todos os seus, e é esse mesmo poder que, dirigido pela vontade geral, ganha, como já disse, o nome de soberania” (ROUSSEAU, 1999, p. 95, grifos meus). 
restituir à instituição e à ordem político-jurídica que a perfaz o conteúdo da vida efetiva e real, abrangendo, em razão dessa necessidade, os momentos referentes à universalidade, à particularidade e à singularidade ${ }^{11}$ por intermédio do movimento dialético de institucionalização que correlaciona instituido e instituinte na constitutividade da totalidade social e determina a sua estrutura como tal. ${ }^{12}$

\section{DA DIALÉTICA ESSENCIAL ENTRE DIREITO E PODER NA CONSTITUIÇÃO DO ESTADO E A VONTADE GERAL COMO PROCESSO ÉTICO-JURÍDICO DE DELIBERAÇÃO COLETIVA E PRINCíPIO DE INTEGRAÇÃO DINÂMICO-DIALÉTICA}

Se Direito e Poder se correlacionam na constitutividade da realidade funcional do Estado, a Vontade Geral não emerge senão como a própria força de coesão social, à medida que implica processo que envolve a objetivação de valores, necessidades e fins que guardam raízes no "eu-comum" e trazem a legislação como

${ }^{11}$ Encerrando a "uniáo do caráter de reflexo que tem o pensamento com a consequente realizaçáo do seu ser um processo", a concepção dialético-materialista da universalidade supera tanto a gnosiologia do materialismo mecanicista quanto o idealismo dialético de Hegel, que converge para uma "mistificação da universalidade", conforme expóe Lukács, que afirma: "A universalidade, sobretudo, não é jamais um ponto de chegada autônomo do pensamento. Marx, na introdução teórica à primeira redação de sua obra econômica, fala de dois caminhos que o conhecimento humano deve percorrer: isto é, da realidade concreta dos fenômenos singulares às mais altas abstraçóes, e destas novamente à realidade concreta, a qual - com a ajuda das abstraçóes - pode agora ser compreendida de um modo cada vez mais aproximativamente exato. (...) De fato, o processo de tal aproximação é essencialmente ligado à dialética de particular e universal: o processo do conhecimento transforma ininterruptamente leis que até aquele momento valiam como as mais altas universalidades em particulares modos de apresentação de uma universalidade superior, cuja concretizaçáo conduz muito frequentemente, ao mesmo tempo, à descoberta de novas formas da particularidade como mais próximas determinaçóes, limitaçóes e especificaçốes da nova universalidade tornada mais concreta" (LUKÁCS, 1978, p. 103).

12 Alcança relevância, nesta perspectiva, o esclarecimento de Kosik acerca da noção de totalidade segundo o método dialético: "O ponto de vista da totalidade concreta nada tem de comum com a totalidade holística, organicista ou neo-romântica, que hipostasia o todo antes das partes e efetua a mitologizaçáo do todo. A dialética não pode entender a totalidade como um todo já feito e formalizado, que determina as partes, porquanto à própria determinaçáo da totalidade pertencem a gênese $\mathrm{e}$ o desenvolvimento da totalidade, o que, de um ponto de vista metodológico, comporta a indagação de como nasce a totalidade e quais são as fontes internas do seu desenvolvimento e movimento. A totalidade não é um todo já pronto que se recheia com um conteúdo, com as qualidades das partes ou com as suas relaçôes; a própria totalidade é que se concretiza e esta concretização não é apenas criação no conteúdo mas também criação do todo" (KOSIK, 1976, p. 58-59, grifos do autor). 
a sua expressão, convergindo para a manifestação da soberania popular. Tal noção, que conjuga vontades e interesses particulares em um movimento de superaçáo que dialoga com o bem comum e acena com uma universalizaçáo que corresponde à ideia de uma unidade social diferenciada, tende a se sobrepor ao caráter formal que a atrela ao conceito abstrato de nação, que encerra uma universalidade que se esgota, em última instância, nas fronteiras que circunscrevem o povo ao âmbito de uma unidade amorfa.

Sobrepondo-se ao normativismo puro que caracteriza o sistema gradativo de prescriçóes, regras e normas que perfaz o arcabouço do Estado em sua condição formal de existência, a Vontade Geral, como um processo ético-jurídico que envolve as decisóes coletivas e, antes, a sua elaboração, converge para atribuir ao Estado a forma de "Estado-função". A referida condição implica possibilidade de que a soberania não se circunscreva às fronteiras que encerram um aspecto do ordenamento jurídico mas guarde raízes no mundo da realidade histórico-cultural e socioeconômica da vida coletiva, expressando a unidade e a validade objetiva de valores e práticas, condutas e comportamentos, necessidades e fins que se lhe emergem.

Que será, pois, propriamente, um ato de soberania? Não é uma convenção entre o superior e o inferior, mas uma convençáo do corpo com cada um de seus membros: convenção legítima por ter como base o contrato social, equitativa por ser comum a todos, útil por não poder ter outro objetivo que não o bem geral, e sólida por ter como garantia a força pública e o poder supremo (ROUSSEAU, 1999, p. 98).

Perfazendo um processo que envolve as decisóes coletivas e, antes, a sua elaboração, ${ }^{13}$ a Vontade Geral não configura senão uma "ação instituinte", emergindo como a condição para o exercício da soberania popular, cuja "essência" acena com a noção de um poder "constituinte", à medida que carrega a possibilidade de

13 Eis os princípios expostos por Gramsci em relação ao momento em questão: "Os componentes da colectividade devem, portanto, pôr-se de acordo, discutir entre eles. Através da discussão, deve resultar uma fusão dos espíritos e das vontades. Os elementos singulares de verdade, que cada um pode oferecer, devem sintetizar-se na complexa verdade e ser a expressão integral da razão. Para que isto se realize, para que a discussão seja exaustiva e sincera, é necessária a máxima tolerância. Todos devem estar convencidos que aquela é a verdade e que, portanto, é preciso necessariamente pô-la em prática” (1976, p. 172, grifos do autor). 
se sobrepor ao Direito positivo da instituição político-social ora identificada sob a acepçáo de Estado, tendo em vista a sua capacidade de se lhe impor, constituindo-o enquanto tal e como tal.

Nessa perspectiva, o que se impóe à Vontade Geral é a possibilidade de superação da condição in abstracto do Estado que, não detendo como fundamento os sujeitos reais, converge para uma subjetivação de caráter místico, consistindo a soberania, dessa forma, em uma "essência” autônoma, objetivada. Tal condição acarreta a necessidade de se lhe atribuir uma noção de poder que não se circunscreva às fronteiras da positividade do Direito mas guarde capacidade de viabilizar a transição do Estado in potentia para o Estado objetivo, conforme supóe o movimento dialético no momento em que emerge como instituinte em um contexto que encerra o momento do instituido ${ }^{14}$ e o momento da institucionalização na instância que não tende senão, diante do referido processo, a perfazer um domínio in concreto.

Atribuir ao sistema de direitos e deveres que perfaz a legislação a necessária relação de correspondência envolvendo a realidade histórico-cultural e socioeconômica concreta, é a capacidade da Vontade Geral, à medida que consiste na objetivação de valores, necessidades e fins do corpo coletivo e moral. Este, embora dependente da estrutura formal e da função normativa da ordem jurídica, tende a superar, dessa forma, a redução da sua existência enquanto tal ao legalismo de uma vida resultante de um processo mecânico e estereotipado que, corporificando o Estado não político, encerra o poder nas fronteiras do Estado político, o qual, em detrimento daquele, detém uma soberania que não se impóe senáo como o exercício da coação incondicionada.

Se a Justiça consiste, em última instância, na ordenação histórica de valores sociais, configurando uma noção que não guarda correspondência senão com as fronteiras do bem comum, a Vontade Geral, como um processo que envolve as decisóes coletivas e, antes, a sua deliberação, converge para a possibilidade que implica realização do Direito por meio do exercício do poder. O processo em questáo, que

14 Se o instituinte consiste em um momento do processo de institucionalização que encerra o movimento de produção do sistema de valores, necessidades e fins que converge, nas fronteiras da instituição, para a constituição do instituído, o instituído configura a condensação do conteúdo que emerge do instituinte, o que implica que, nesta relação, "o instituinte aparece como um processo, enquanto o instituido aparece como resultado" (LAPASSADE, 1989, p. 30, grifos meus). 
representa a unidade e a validade de um sistema de normas que tende à universalidade que a institucionalização instaura, perfaz o Estado enquanto estrutura formal na relação dialética que traz como conteúdo os homens enquanto indivíduos em sua concreticidade histórico-cultural e socioeconômica. ${ }^{15}$

Não basta que o povo reunido tenha uma vez fixado a constituiçáo do Estado sancionando um corpo de leis; não basta, ainda, que tenha estabelecido um Governo perpétuo ou que, de uma vez por todas, tenha promovido a eleiçáo dos magistrados; além das assembléias extraordinárias que os casos imprevistos podem exigir, é preciso que haja outras, fixas e periódicas, que nada possa abolir ou adiar, de tal modo que, no dia previsto, o povo se encontre legitimamente convocado pela lei, sem que para tanto haja necessidade de nenhuma outra convocação formal (ROUSSEAU, 1999, p. 181).

Nessa perspectiva, o que se impóe à Vontade Geral é a possibilidade de renovação da adesão dos homens enquanto indivíduos em sua concreticidade histórico-cultural e socioeconômica ao ideal comum concretizado pelo Estado como uma forma institucional para a qual converge o sistema de valores que do processo ético-jurídico de deliberação coletiva resulta, emergindo de um movimento econômico-político que abrange os momentos constitutivos da totalidade sociopolítico-jurídica e perfaz a unidade de ordem que se lhe impóe. Tal processo se sobrepóe à noçáo de poder que se circunscreve às fronteiras da exterioridade coercitiva e à concepção de soberania como a supremacia do esqueleto estatal em detrimento das partes que o compóem e que o formam como uma estrutura cuja natureza se lhes deve corresponder, sob pena de perder a vitalidade que possibilita a recuperação do conteúdo em razão do qual teoricamente veio a existir e que não se permite desatualizar, tendo em vista a relação que cabe manter com as subjetividades empíricas em um determinado contexto histórico.

15 Nesta perspectiva, alcança relevância a conclusão para a qual converge a interpretação de Cassirer acerca da teoria política rousseauniana: "À idéia do Estado do bem-estar e do poder, opóe a idéia do Estado de Direito. E neste caso para ele [Rousseau] não existe meio-termo; ele conhece apenas ou um ou outro" (CASSIRER, 1999, p. 68). 
Se a "vontade de todos", permanecendo à mercê do poder das maiorias momentâneas, não guarda capacidade de corresponder ao Estado como uma forma institucional de caráter permanente e cuja existência supóe uma unidade de ordem que não pode se circunscrever ao arcabouço jurídico - este, pois, sob a acepção de um aparelho coativo que atribui à totalidade ético-jurídica a soberania que, embora formal, lhe é devida -, o que se impóe à Vontade Geral é um processo ético-jurídico de integração dinâmico-dialética que traz como fundamento um fim comum e que se manifesta por meio de um movimento econômico-político de objetivaçáo de valores, necessidades e fins do povo enquanto corpo coletivo e moral. ${ }^{16}$

Nessa perspectiva, a Vontade Geral emerge como possibilidade de correspondência entre norma e realidade mediante o processo ético-jurídico de deliberação coletiva que implica objetivação de valores, necessidades e fins do corpo coletivo e moral que converge para as fronteiras que encerram o movimento de institucionalização e tende, desse modo, à construção da universalidade concreta ${ }^{17}$ que se impóe à Constituição e às leis. Dessa forma, a Constituição e as leis, sobrepondo-se ao caráter abstrato que se lhe atribui a perda do conteúdo histórico e da sua densidade, recuperam a vitalidade que se lhe outorga a capacidade de regular o complexo

${ }^{16}$ Eis o argumento rousseauniano: "Deve-se compreender, nesse sentido, que, menos do que o número de votos, aquilo que generaliza a vontade é o interesse comum que os une, pois nessa instituição cada um necessariamente se submete às condiçóes que impóe aos outros: admirável acordo entre o interesse e a justiça, que dá às deliberaçôes comuns um caráter de equidade que vimos desaparecer na discussáo de qualquer negócio particular, pela falta de um interesse comum que una e identifique a regra do juiz à da parte" (ROUSSEAU, 1999, p. 97).

17 Nesta perspectiva, cabe sublinhar que a dialética materialista, conforme argumenta Lukács, "na medida em que ela realiza e desenvolve a aproximação à realidade objetiva conjuntamente ao caráter processual do pensamento como meio para esta aproximaçáo, pode compreender a universalidade em uma contínua tensão com a singularidade, em uma contínua conversão em particularidade e vice-versa. Assim a concreticidade do conceito universal é purificada de qualquer mistificação, é concebida como o veículo mais importante para conhecer e dominar a realidade objetiva. Engels formulou de um modo sugestivo este caráter da universalidade concreta: 'Abstrato e concreto. A lei geral da modificaçáo de forma do movimento é muito mais concreta do que qualquer exemplo singular 'concreto' dela"' (LUKÁCS, 1978, p. 104). 
movimento de integração dos homens enquanto indivíduos em sua concreticidade histórico-cultural e socioeconômica ao Estado, perfazendo-o como totalidade sociopolítico-jurídica. ${ }^{18}$

Esgotando-se no significado formal da Constituição e das suas leis, à medida que a relação que mantém com o arcabouço que se impóe ao Estado transcende a realidade concreta das subjetividades empíricas, das unidades sociais particulares, das forças sociais em ação, se a "vontade de todos" guarda, consequentemente, um caráter abstrato, a Vontade Geral converge para se lhes conferir um significado substancial, se lhes restituindo o conteúdo da vida social e se lhes tornando uma realidade integrante. ${ }^{19}$

Se o equilíbrio social escapa à possibilidade de concretização por meio de um suposto funcionamento automático dos mecanismos e dos dispositivos que se correlacionam no arcabouço jurídico, segundo a concepção que pretende a eliminação da forma institucional do Estado e a exclusão do poder em virtude da relação de exterioridade coercitiva que o seu exercício, nesta perspectiva, implica, à Vontade Geral o que se impóe é a capacidade de atribuir uma condição de complementarie-

18 Nesse sentido, recorrendo à leitura de Marx, convém sublinhar: "O Estado existe somente como Estado politico. A totalidade do Estado político é o poder legislativo. Tomar parte no poder legislativo é, por isso, tomar parte no Estado político, manifestar e realizar sua existência como membro do Estado político, como membro do Estado. Que, portanto, todos singularmente queiram participar no poder legislativo náo é senão a vontade de todos de ser membros reais (ativos) do Estado ou de se dar uma existência política ou de manifestar e realizar sua própria existência como existência política" (MARX, 2010, p. 132, grifos do autor).

19 Nesta perspectiva, cabe salientar que, conforme afirma Gramsci, "não se concebe vontade que não seja concreta, isto é, que não tenha uma finalidade. Não se concebe vontade colectiva que não tenha uma finalidade universal concreta. Mas isto náo pode ser um facto singular ou uma série de factos singulares. Pode ser só uma ideia ou um princípio moral. O defeito orgânico das utopias está todo aqui: acreditar que a previsão possa ser previsão de factos, enquanto só o pode ser de princípios ou de máximas jurídicas. As máximas jurídicas (o direito é a moral actuada) são criaçôes dos homens como vontade. Se quiserem dar a esta vontade uma certa direcção, ponham-lhes como finalidade o que só pode sê-lo; de outro modo, depois do primeiro entusiasmo, vê-las-âo aviltar-se e perder-se" (GRAMSCI, 1976, p. 114). 
dade ao vínculo entre Direito e poder ${ }^{20}$ superando o caráter autoexcludente se lhe conferido pela leitura que defende a harmonização espontânea das vontades particulares e dos interesses que se lhe estão atrelados no âmbito das forças produtivas.

\title{
3 DA CONVERSÃO DA VONTADE GERAL EM LEGISLAÇÃO COMO OBJETIVAÇÃO DE VALORES, NECESSIDADES E FINS DO CORPO COLETIVO E MORAL
}

\begin{abstract}
Se quisermos saber no que consiste, precisamente, o maior de todos os bens, qual deva ser a finalidade de todos os sistemas de legislação, verificar-se-á que se resume nestes dois objetivos principais: a liberdade e a igualdade. A liberdade, porque qualquer dependência particular corresponde a outro tanto de força tomada ao corpo do Estado, e a igualdade, porque a liberdade não pode subsistir sem ela (ROUSSEAU, 1999, p. 127, grifos do autor).
\end{abstract}

Ao processo que envolve a conversão da Vontade Geral em legislação o que se impóe é a criação de condiçôes histórico-culturais e socioeconômico que possibilitem a objetivação de valores, necessidades e fins que caracterizam o povo enquanto corpo coletivo e moral e perfaz um arcabouço cuja emergência demanda a construção de relaçôes sociais capazes de viabilizar a experiência que implica vivência do interesse comum, base identitária que se sobrepõe à reuniáo de indivíduos e as suas vontades particulares. Se tal condição guarda a acepção que converge para a agregação e não transpóe as fronteiras que encerram a vontade de todos (maioria), distinguindo-se

20 “O único poder 'legítimo' é o poder que exerce o princípio da legitimidade como tal e a ideia da própria lei sobre as vontades individuais. Essa ideia requer o indivíduo apenas como membro da comunidade, como órgáo co-participante da vontade geral, mas não em sua essência e existência particular. Não se pode conceder nenhum privilégio especial a um indivíduo enquanto individuo, ou a uma classe especial; não se pode exigir dele nenhum desempenho especial. Neste sentido, a lei não pode reconhecer qualquer 'prestígio pessoal'. Assim, uma ligação que pretende ligar não a todos simplesmente, mas apenas este ou aquele anula-se a si própria. Não pode, nem deve haver nenhuma exceçâo no interior do direito e em virtude do direito; ao contrário, toda determinação excepcional à qual cidadãos isolados, ou determinadas classes estáo submetidos significa eo ipso a aniquilação da ideia de direito e de Estado: a dissolução do pacto social e a recaída no estado natural, que neste contexto se caracteriza como puro estado de violência" (CASSIRER, 1999, p. 59). 
da união social, esta carrega a noção de intersecção abrangendo o geral e o particular e supóe uma vontade que não acena senão com a "soma das diferenças", da qual se lhe resulta como tal, a saber, Vontade Geral (Vontade Coletiva). ${ }^{21}$

Emergindo como a possibilidade de conferir à Constituiçẫo a condição que requer um sistema de caráter vivo diante da capacidade que se lhe está atrelada de corresponder às múltiplas demandas da vida concreta, a emergência da Vontade Geral não guarda relação senão com uma manifestação que, envolvendo valores e práticas, condutas e comportamentos, necessidades e objetivos que ecoam dos indivíduos e de suas vontades particulares, convergem para a unificação que as fronteiras do interesse comum contemplam, tendo em vista que é como membros do soberano que encerram a disposição de expressar o que somente o exercício da cidadania plena se lhes expóe.

A primeira e mais importante conseqüência decorrente dos princípios até aqui estabelecidos é que só a vontade geral pode dirigir as forças do Estado de acordo com a finalidade de sua instituiçấo, que é o bem comum, porque, se a oposição dos interesses particulares tornou necessário o estabelecimento das sociedades, foi o acordo desses mesmos interesses que o possibilitou. O que existe de comum nesses vários interesses forma o liame social e, se não houvesse um ponto em que todos os interesses concordassem, nenhuma sociedade poderia existir. Ora, somente com base nesse interesse comum é que a sociedade deve ser governada (ROUSSEAU, 1999, p. 85, grifos meus).

Nessa perspectiva, o que se impóe à Vontade Geral é a unidade concreta da organização social, para cujas fronteiras convergem os valores e as práticas, as condutas e os comportamentos, as necessidades e os objetivos que resultam das relaçôes correspondentes às forças produtivas e ao seu complexo dinâmico-contraditório. Dessa forma, a Vontade Geral guarda, enquanto tal, a possibilidade de que as atividades que implicam a vida coletiva e a realidade concreta se

${ }_{21}$ Tendo em vista que "não é pelo simples estatuto jurídico que se regulam as relaçôes entre os seus membros, que uma república se distingue de simples agregado. O que distingue estas duas formas de ordenaçáo social é a natureza do laço pelo qual se prendem uns aos outros os seus membros. Numa pátria, os associados possuem todos uma só vontade e um só interesse, ao passo que na outra forma de associação a união que se verifica não vai além da simples justaposição dos egoísmos individuais" (FORTES, 1976, p. 90, grifos meus). 
sobreponham ao caráter formal que transforma as normas e os preceitos, os textos e os regulamentos que perfazem o seu estatuto (Constituição) em construçôes sem sentido, que acenam com um ideal de existência que escapa ao contexto histórico-cultural e socioeconômico e ao homem que, do seu arcabouço, emerge e com as suas determinaçôes não se lhe facultam as circunstâncias prescindir do diálogo, à medida que a transcendência desse processo se lhe mantém dependência, sob pena de se tornar contraproducente o seu movimento, anulando os efeitos que pretendia e se lhe cabia produzir.

Não guardando correspondência senão com os homens enquanto indivíduos em sua concreticidade histórico-cultural e socioeconômica, os quais, em função das referidas especificidades, detêm vontades e interesses que se opóem e por meio das suas diferenças convergem para as fronteiras da complementariedade, à Vontade Geral o que se impóe é um processo que envolve a objetivação de valores, necessidades e fins que emergem das estruturas que perfazem a constituição da ordem social. Tal processo encerra uma positividade que se sobrepõe ao "dever-ser" in abstracto e alcança um horizonte que o mantém atrelado ao âmbito que implica o "enquanto é" em uma relação dialética que abrange o real e o possível no que diz respeito à forma da existência e à necessidade de se lhe adaptar, simultaneamente se lhe transformando.

Configurando um processo que converge para as fronteiras que encerram uma "ação instituinte", a Vontade Geral tende a assumir a condição de realidade "institucionalizada" por meio da sua corporificação na legislação, o que implica necessidade constante da emergência da unidade negativa da forma social em questâo, perfazendo um contexto que abrange o conjunto das forças sociais em ação e as relaçôes envolvendo instituição e estrutura, instituição e sistema, instituição e organização, e acena com a possibilidade de superaçáo da ordem estabelecida. E isto se impóe à medida que o conteúdo "positivo" consubstanciado pelos valores, necessidades e objetivos do sistema é transformado pela dinâmica, pela negatividade e pela contraditoriedade que caracterizam o sentido ativo imposto pelo movimento que se desenvolve em razão de três momentos que perpassam o referido processo: o da universalidade, o da particularidade, o da singularidade. 
Nessa perspectiva, a Vontade Geral consiste na possibilidade e, antes, na condição para que o arcabouço da legislaçáo não se circunscreva ao horizonte da formulação abstrata, à medida que se lhe impóe a necessidade de corresponder a realidades objetivas e se constituir mediante um substractum de ordem político-social. Tal condição possibilita a superação do reducionismo que pretende relegar a experiência do exercício da soberania popular à esfera técnico-formal do sistema representativo, cuja noção de instituição, guardando raízes nas fronteiras da ideologia e veiculando valores, necessidades e objetivos que lhe são correspondentes, permanece atrelada a uma concepção positivista, caracterizada como transcendente ante as relaçóes sociais reais.

Longe de se caracterizar como expressão pura e exclusiva das exigências éticas, a Vontade Geral como um processo que envolve as decisóes coletivas e, antes, a sua elaboração, converge para as fronteiras que encerram a sua subordinação ao âmbito das circunstâncias contingentes, as quais não tendem senão a se sobrepor ao acordo universal que se impóe à concretização de valores e práticas, condutas e comportamentos, necessidades e objetivos que hão de consubstanciar o sistema de direitos e deveres da organização social. A referida condição implica igualdade substantiva capaz de não se circunscrever à esfera "política" e à condição "negativa" que esta lhe atribui, isto é, uma igualdade material, que perfaz a única possibilidade de diálogo entre a realidade histórico-cultural e econômico-social e os fins éticos da convivência humana, tornando o interesse comum "in concreto", tendo em vista que

o pacto social estabelece entre os cidadáos uma tal igualdade, que eles se comprometem todos nas mesmas condiçóes e devem gozar todos dos mesmos direitos. Igualmente, devido à natureza do pacto, todo o ato de soberania, isto é, todo o ato autêntico da vontade geral, obriga ou favorece igualmente todos os cidadáos, de modo que o soberano conhece unicamente o corpo da naçáo e não distingue nenhum dos que a compóem (ROUSSEAU, 1999, p. 97-98).

Nessa perspectiva, consistindo em um "poder-dever" que se sobrepõe a um puro sistema de direitos e deveres que escapa ao diálogo com as fronteiras dos valores, o processo que implica Vontade Geral e que envolve as decisóes coletivas e, antes, a sua deliberação, na medida em que guarda raízes na sociabilidade concreta, traz em seu âmago a realidade histórico-cultural e econômico-social e os fins éticos inerentes 
às relaçóes dos homens entre si no arcabouço das forças produtivas, convergindo para a capacidade de conferir gradualmente positividade ao direito do povo real, concretizando o seu poder por meio da ordem jurídica.

\title{
4 DA VONTADE GERAL COMO PROCESSO ÉTICO-JURÍDICO DE DECISÃO COLETIVA E FORMA DE EXERCÍCIO DO PODER ECONÔMICO-POLÍTICO
}

\begin{abstract}
Os assuntos universais do Estado são os assuntos estatais, o Estado enquanto assunto real. A deliberaçáo e a decisão são a realização do Estado enquanto assunto real. Parece evidente, portanto, que todos os membros do Estado têm uma relação com o Estado como seu assunto real. Encontra-se já no conceito de membro estatal que eles são, cada um, um membro do Estado, uma parte dele, que ele os toma como sua parte. Mas, se eles são uma parte do Estado, é evidente que sua existência social é, desde já, sua real participação no Estado. Eles não são apenas parte do Estado, mas o Estado é sua parte. Ser parte consciente de alguma coisa é lhe tomar, com consciência, uma parte, participar nela conscientemente (MARX, 2010, p. 132, grifos do autor).
\end{abstract}

Condição que viabiliza que ao exercício do poder seja atribuído o caráter do exercício de um direito, eis o que se impóe à Vontade Geral, à medida que emerge como um processo que envolve as decisóes coletivas e, antes, a sua deliberação, que consiste na objetivação de valores e práticas, condutas e comportamentos, necessidades e fins do corpo coletivo e moral que convergem para um sistema de deveres e sançôes que perfaz, em sua concreticidade, o consenso na sua positividade, qual seja, a Constituição.

Nesta perspectiva, a Vontade Geral consiste na superação da noção de poder à redução que implica pura categoria jurídica que se sobrepóe aos homens enquanto indivíduos em sua concreticidade histórico-cultural e econômico-social e às unidades sociais particulares das quais participam, perfazendo uma autoridade que se impóe em virtude de uma instituiçáo que se esgota como uma estrutura formal, um arcabouço de valores e práticas, condutas e comportamentos, neces- 
sidades e objetivos existentes a priori, o qual, diante da sua condição metafísica e trans-histórica, prescinde dos liames que abrangem a realidade humana, sendo, por essa razão, destituído do conteúdo que somente esta é capaz de engendrar. ${ }^{22}$

Caracterizando-se como a restituição do conteúdo que emerge da realidade humana à ordem jurídica que perfaz a estrutura formal da instituição político-social, à medida que, por intermédio do processo que implica sua manifestação, converge para o exercício da soberania popular, a Vontade Geral dialoga com uma noção de poder que se sobrepóe à condição de um fenômeno objetivo que se impóe à subjetividade dos indivíduos por meio da coercitividade, consistindo, diferentemente, na expressão da unidade social, cuja instauração, baseada em um interesse, um fim comum, detém a possibilidade de correlacionar poder de fato e poder de direito.

"Não tendo, o soberano, outra força além do poder legislativo, só age por meio das leis, e não sendo estas senão atos autênticos da vontade geral, o soberano só poderia agir quando o povo estivesse reunido" (ROUSSEAU, 1999, p. 179). Nessa perspectiva, o que se impóe é a complementariedade que caracteriza a relação que envolve Poder e Direito, perfazendo um princípio que a Vontade Geral encerra, à medida que implica processo que envolve as decisóes coletivas e, antes, a sua elaboração, cuja condição converge para a soberania popular, que consiste nos atos gerais e, na sua expressão, as leis, ${ }^{23}$ não configurando senão a sua manifestação o exercício da autonomia do corpo coletivo e moral por meio de uma noçáo que tende a se sobrepor ao caráter formal que guarda correspondência com o conceito abstrato de nação.

22 Nesta perspectiva, cabe salientar que, divergindo da interpretação de Durkheim, o fundamento da obrigação, segundo a teoria de Rousseau, "não implica de modo algum que exista uma autoridade externa e superior aos indivíduos, autoridade que impóe seu respeito", mas converge para assinalar que "a autoridade política tem seu fundamento no ato pelo qual o indivíduo se engaja em obedecer à vontade geral” (DERATHÉ, 2009, p. 351).

23 Tendo em vista a concepção que, trazendo como fundamento a questão proposta por Proudhon, a saber, “O que é entấo o povo se não é soberano, se náo é dele que vem o poder legislativo?”, converge para a seguinte perspectiva: "O povo é o guarda da lei, o povo é o poder executivo. Todo o cidadão pode afirmar: Isso é verdadeiro: isso é justo; mas a sua convicção só o obriga a ele: para que a verdade que proclama se torne lei é preciso que seja reconhecida. Ora, que significa reconhecer uma lei? É verificar uma operação matemática ou de metafísica; é repetir uma experiência, observar um fenómeno, verificar um facto. Só a nação tem o direito de dizer: Mandamos e ordenamos" (PROUDHON, 1975, p. 240, grifos do autor). 
Se a estrutura jurídica não se caracteriza senão como um sistema estático, à medida que se lhe cabe conferir estabilidade às relaçóes envolvendo os homens e as unidades sociais particulares entre si, à Vontade Geral o que se impóe é a necessidade de estabelecer a compatibilidade com a vida, que implica a restituição à ordem em questão (vigente) o conteúdo que emerge da realidade histórico-cultural e econômico-social. Tal possibilidade converge para se lhe conferir a dinâmica própria a uma organização em movimento, cujo funcionamento se sobrepóe ao sentido de uma mera correlação mecânica de normas e preceitos que cumpre nortear a atividade humana, produzindo, pela sua força, a integraçáo devida, a qual, nesta perspectiva, supóe, em nome da objetividade, a redução da subjetividade e a eliminação das particularidades.

Condição que converge para as fronteiras que encerram a realização do direito do povo, a saber, a soberania, a Vontade Geral consiste no poder que, trazendo como fundamento as relaçóes de interdependência envolvendo os homens e as unidades sociais particulares entre si, detém a capacidade de intervir na realidade jurídico-política e conferir ao Direito abstrato a positividade que a sua aplicação demanda e que guarda correspondência com as necessidades individuais e coletivas.

Nessa perspectiva, o que cabe à Vontade Geral é a possibilidade da instauração de uma relação dialética envolvendo o complexo de fatos e valores que se impóe por meio das relaçóes dos homens enquanto indivíduos em sua concreticidade histórico-cultural e econômico-social e as unidades sociais particulares entre si (e que náo se caracterizam senão como elementos condicionantes) e o arcabouço jurídico e as suas normas e preceitos, convergindo para as fronteiras que encerram a atualização do Direito. Tal condição se impóe à medida que instaura um processo que envolve as decisóes coletivas e, antes, a sua elaboração, que, trazendo como fundamento valores e práticas, condutas e comportamentos, necessidades e objetivos do conjunto das forças sociais em ação em uma situação comum, consiste na condição para o exercício da soberania popular, constituindo-se em um poder de fato, não somente em um poder de direito.

À participação no processo de construção da Vontade Geral o que se impóe é a condição para que o homem, por meio da relação dialética envolvendo o seu interesse, a sua vontade e a sua liberdade como indivíduo, e a situação comum e o caráter do interesse, da vontade e da liberdade que se lhe impóe, supere a individu- 
alidade abstrata que tende a separá-lo da comunidade, estabelecendo uma ruptura que, ante a totalidade social, circunscreve-o a si. Esta condiçâo se lhe atribui uma independência incompatível com a lógica da organização do poder que a existência e o funcionamento do sistema social implica e que supóe interdependência e intersubjetividade, não a justaposição de "consciências de si" e de "eus" que guardem imunidade entre si, usufruindo uma igualdade formal e uma "justiça" que não dialogam com a realidade concreta, correspondendo apenas ao viés ideológico do arcabouço político-jurídico da ordem em vigor. ${ }^{24}$

Se há uma ruptura envolvendo moralidade e legalidade, que converge para um dualismo que mantém sob a acepção de uma realidade de caráter interior a primeira e a segunda no sentido de uma realidade de caráter exterior, opondo o mundo subjetivo, que encerra parcialidade e negatividade, e a vida social real, que perfaz a totalidade do arcabouço ético, o que se impóe à Vontade Geral não é senão a possibilidade de sua superação, à medida que estabelece uma relação dialética entre ambas no processo que implica sua emergência como tal, convergindo, por meio da objetivaçáo de valores, necessidades e fins que consistem no seu conteúdo para uma Constituição e um sistema político-jurídico que, guardando raízes nas fronteiras do interesse comum e do bem que se lhe está imbricado, trazem como fundamento a vida concreta do povo. ${ }^{25}$

Nessa perspectiva, a Vontade Geral consiste na possibilidade de superação das abstraçóes formais que tendem a caracterizar o arcabouço constitucional e o sistema político-jurídico em nome da estabilidade que as formas institucionalizadas propor-

${ }_{24}$ Tendo em vista a concepção que sublinha que "a liberdade na desigualdade é o privilégio, isto é, a felicidade de alguns fundada sobre o sofrimento de todos", conforme esclarece Bakunin, que defende a instauração da necessária correlação envolvendo igualdade política e igualdade econômica, à medida que "a igualdade política sem igualdade econômica é uma farsa, uma mentira" (1979, p. 6).

25 Eis a advertência de Rousseau: "Cada um, desligando seu interesse do interesse comum, bem sabe que não o pode isolar completamente; sua parte do mal público, porém, não lhe parece nada, em face do bem exclusivo de que pretende apropriar-se. Excetuado esse bem particular, ele deseja, tão fortemente quanto qualquer outro, o bem geral em seu próprio interesse. Mesmo quando vende seu voto a peso de dinheiro, não extingue em si a vontade geral - ilude-a. A falta que comete é mudar a natureza da questão e responder coisa diversa que se lhe pergunta, de modo que, em lugar de dizer, com seu voto, 'é vantajoso ao Estado', ele diz 'é vantajoso para tal homem ou tal partido que seja aprovada tal ou qual proposta'. Assim, a lei da ordem pública nas assembleias não está tanto em nelas manter a vontade geral, quanto em fazer com que sempre seja consultada e sempre responda" (ROUSSEAU, 1999, p. 200-201). 
cionam, à medida que, como uma "força instituinte", converge para as fronteiras que restituem à instituiçâo o conteúdo que encerra os valores, as necessidades e os objetivos que emergem das relaçóes dos homens enquanto indivíduos em sua concreticidade histórico-cultural e econômico-social e as unidades sociais particulares entre si. Tal condição envolve, nos momentos que perfazem o referido processo, a saber, os momentos da universalidade, da particularidade e da singularidade, ${ }^{26} \mathrm{um}$ movimento que acena com a totalidade do sistema e cuja dinâmica dialoga com o que é essencial para o seu funcionamento correspondendo à natureza dos que o compóem, ou seja, a vitalidade ética.

\section{ASPECTOS CONCLUSIVOS}

Caracterizando-se como um ser em relação com as determinaçóes que se impóem à existência histórico-cultural e econômico-social, se a vontade converge para a produção de um conteúdo que não consiste senão em uma forma de relação que acena com um movimento que instaura em sua experiência o aspecto lógico (superação) e o aspecto ético (reconhecimento recíproco), o que se impóe à Vontade Geral, mediante a negatividade inscrita entre os homens enquanto indivíduos em sua concreticidade histórico-cultural e econômico-social e os valores e práticas, condutas e comportamentos, necessidades e objetivos que perfazem a instituição ora designada como Estado, que configura o instituído que encerra em si, em última instância, a ordem político-jurídica, é uma nova relação envolvendo o sujeito e a comunidade; e isto tendo em vista o processo que, concernente à substancialidade ética, implica a sua mediação, abrangendo a fixação dos limites que demandam a vida comunitária, desde a dissolução dos indivíduos ou da atribuição de uma condição

${ }^{26}$ Recorrendo à perspectiva de Lourau (1996), cabe esclarecer que, em última instância, se o conceito de instituição, em seu momento da universalidade, guarda correspondência com o conteúdo da ideologia, dos sistemas de normas, dos patterns (padrōes), dos valores que guiam a socialização, em seu momento da particularidade náo perfaz senâo o conjunto das determinaçôes materiais e sociais que converge para negar a universalidade imaginária do primeiro momento, emergindo o referido conceito, em seu momento de singularidade, sob a égide das formas organizacionais, jurídicas ou anômicas, que se impóem como necessárias para atingir um determinado objetivo ou finalidade. 
concreta ao ser que se detém na abstraçãoo, ${ }^{27}$ até a resolução das suas oposiçôes, que guarda correspondência com os momentos da universalidade, da particularidade $\mathrm{e}$ da singularidade e com a dinâmica que os une à totalidade social.

Se o conjunto de prescriçóes, regras e normas que perfaz a estrutura legislativa tende a convergir para o horizonte da pura formalidade, relegando-a ao arcabouço de arquétipos que caracteriza o formalismo normativista e uma noção de soberania atrelada a um conceito de instituiçấo que exclui o substractum da realidade da vida coletiva dos homens enquanto indivíduos em sua concreticidade histórico-cultural e econômico-social, o que se impóe à Vontade Geral não é senão que a sua emergência guarda possibilidade de instaurar uma carga de motivos de ordem ética e material que se lhe mantenha correspondência, conferindo ao Direito o caráter de um sistema vivo. Tal condiçấo, longe de deflagrar a tirania das estruturas mortas sobre o destino da organização social em vigor, restitui à noção de poder e autoridade, Vontade (Geral) e soberania (popular) o conteúdo originário, cuja "essência", expressão da unidade e da validade objetiva do sistema, não detém raízes senão no interior da esfera jurídica que, sob a acepçáo de instituído, encerra uma positividade que, embora configurando o momento da universalidade, não deixa de participar da correlação que abrange os momentos da particularidade e da singularidade que acenam com as oposiçôes entre forma e conteúdo, reprodução e produção, relaçôes e normas que se integram à totalidade e fomentam o movimento da sua própria superação.

Nessa perspectiva, a Vontade Geral não perfaz senão a superação de uma ordem abstrata, cuja universalização se detém nas fronteiras da formalidade, não se constituindo senão pelas parcialidades e contradiçóes, conforme pressuposto no império do direito privado que converge para uma transcendência que, guardando correspondência com a institucionalização da propriedade e as implicaçôes que

${ }^{27}$ Haja vista a perspectiva que assinala que "a dialética de universal e particular na sociedade tem uma função de grande monta; o particular representa aqui, precisamente, a expressão lógica das categorias de mediação entre os homens singulares e a sociedade", conforme esclarece Lukács, que conclui: "Assim, Marx - nos Manuscritos Econômico-Filosóficos - diz: 'Deve-se evitar, sobretudo, fixar a 'sociedade' como uma abstração em face do indivíduo. $\mathrm{O}$ indivíduo é ente social. A sua manifestação de vida - mesmo que não apareça na forma direta de uma manifestação de vida comum, realizada ao mesmo tempo com outros - é, portanto, uma manifestação e uma afirmação de vida social. A vida individual e a vida genérica do homem não são distintas, ainda que - necessariamente - o modo de existência da vida individual seja um modo mais particular ou mais geral de vida genérica, e a vida genérica seja uma mais particular ou mais geral vida individual'” (LUKÁCS, 1978, p. 93, grifos do autor). 
carrega a sua condição de fundamento da organização social, caracteriza-se como falsa, tendo em vista que confere a todo homem a possibilidade de satisfação das suas necessidades de acordo com a sua capacidade de ocupar e transformar a "natureza", impondo aos demais tal "direito".

Se a igualdade formal e o antagonismo real, o sistema e a contradição, a ordem e a desordem, caracterizam as relaçóes envolvendo os homens enquanto indivíduos em sua concreticidade histórico-cultural e econômico-social e as unidades sociais particulares entre si no âmbito do jogo das forças produtivas, o que se impóe é a superação de uma forma institucional que, baseada no direito de propriedade e na divisão do trabalho, uma de suas implicaçóes, converge para a organização de um poder que, tendo a "ocupação" e a "transformação" como exercício, contempla um arcabouço político-jurídico que se funda na "força” e acena com uma ordem abstrata que dialoga com uma universalização formal. ${ }^{28}$ Tal condição se impóe à medida que perfaz um sistema instável que não funciona senão para corresponder às necessidades particulares e aos interesses privados em um contexto que atribui ao homem uma individualidade que guarda raízes no humanismo metafísico, conferindo ao trabalho que se lhe cabe desenvolver uma generalidade abstrata, que lhe imputa a positividade de uma "formação" que não se coaduna com o resultado da sua atividade efetiva, na qual não se expóe de modo algum sob a acepção que o supóe como ativo genericamente, configurando-se, em suma, como instaurador de um regime de desigualdade e injustiça.

28 Recorrendo à análise de Poulantzas acerca do funcionamento de um sistema econômico-social baseado na separação entre o produtor e os meios de produçáo, cabe afirmar que "a superestrutura jurídico-política do Estado está relacionada com essa estrutura das relaçôes de produção, o que se torna claro desde que nos reportamos ao direito capitalista. A separaçấo entre o produtor direto e os meios de produção reflete-se aí através da fixação institucionalizada dos agentes de produção como sujeitos jurídicos, isto é, como indivíduos-pessoas políticos. Isto é tanto verdade, no que diz respeito a essa transaçáo particular que é o contrato de trabalho, a compra e a venda da força de trabalho, como no que concerne à relaçăo de propriedade jurídica formal dos meios de produção ou às relaçôes institucionalizadas públicas-políticas. Isto quer dizer que, de fato, os agentes da produção não aparecem como "indivíduos" a não ser nessas relações superestruturais que são as relaçôes jurídicas. É destas relaçôes jurídicas, e não das relaçóes da produção em sentido estrito, que decorrem o contrato de trabalho e a propriedade formal dos meios de produção" (POULANTZAS, 1977, p. 124). 
Sobrepondo-se ao individualismo e ao imperialismo jurídico, cujo exercício demanda tanto a coordenação quanto a subordinação sob a acepção de formas de Direito, a Vontade Geral consiste em um processo ético-jurídico de deliberação coletiva que converge para a objetivação de valores, necessidades e fins do corpo coletivo e moral por meio de um movimento econômico-político que encerra os momentos que abrangem o instituído, o instituinte e a institucionalização e perfaz a totalidade sociopolítica e jurídica para a qual tende os homens enquanto indivíduos em sua concreticidade histórico-cultural e socioeconômica. Tal condiçáo implica princípio de integração (dinâmico-dialética) que supera a relação de dependência absoluta do sujeito enquanto parte de um todo que se lhe sobrepóe e o anula, como também, contrariamente, a sua independência abstrata, que pressupóem um poder que, inescapavelmente, guarda correspondência com a noção de exterioridade coercitiva e com a concepção de aparelho coativo que está atrelada ao arcabouço jurídico.

Nessa perspectiva, o que se impóe é a necessidade de superaçáo do antagonismo envolvendo o Direito e a vida, tendo em vista a incapacidade do arcabouço jurídico diante das questóes que emergem do âmbito econômico-social e guardam correspondência, em suma, com a subsistência e a vida, que encerram uma condiçáo que escapa ao domínio dos mecanismos e dos dispositivos que se impóem à regulação das relaçóes dos homens enquanto indivíduos em sua concreticidade histórico-cultural e econômico-social entre si e as unidades sociais particulares. Dessa forma, como movimento econômico-político de objetivação de valores, necessidades e fins do povo enquanto corpo coletivo e moral, a Vontade Geral carrega a possibilidade da instauração da atualização dos sistemas legais, se lhes conferindo a vitalidade que um conteúdo novo carrega. ${ }^{29}$

À redução da diversidade empírica dos fatos concretos à unidade abstrata de uma regra, eis o que se impóe ao arcabouço jurídico, que converge para submeter ao império do instituído e da sua forma os homens enquanto indivíduos em sua concreticidade histórico-cultural e socioeconômica, tendo em vista a presunção

29 Tendo em vista que a teoria de Rousseau defende que a "constituição só existe pela vontade do soberano, o qual pode mudá-la quando lhe apraz. As leis do Estado, inclusive as leis fundamentais, são apenas a expressáo da vontade geral. Basta, portanto, que essa vontade mude para que as leis estabelecidas sejam revogadas e substituidas por outras: a autoridade que as dita pode também aboli-las" (DERATHÉ, 2009, p. 483, grifos meus). 
de universalidade que carrega em razão da sua capacidade de durar. Tal processo, contudo, demanda a atualização do seu conteúdo sob pena de perder o vínculo de correspondência com as condiçóes objetivas da vida social, tornando-se um sistema "morto" que, por essa razáo, depende da coação para reger a existência histórico-social que, nesta perspectiva, não emerge senão como uma "existência legal".

Escapando ao sentido que envolve uma emanação "natural" dos fatos sociais, a regra de Direito depende de um poder que a instaure diante das forças sociais, superando a resistência das vontades particulares e dos interesses que se lhe estão atrelados ${ }^{30}$ à medida que não consiste senão em uma composição de forças estabelecida sob a égide de um imperativo ético que implica processo ético-jurídico de deliberação coletiva que, por meio de um movimento econômico-político, converge para a objetivação de valores, necessidades e fins do povo enquanto corpo coletivo e moral, tendo em vista que o que se impõe é tanto a afirmação da positividade do Direito quanto a sua prática, a sua realização efetiva.

\section{REFERÊNCIAS}

BAKUNIN, Mikhail Aleksandrovitch. O socialismo libertário. Trad. Olinto Beckerman. São Paulo: Global, 1979. (Col. bases 22/teoria).

CASSIRER, Ernst. A questão Jean-Jacques Rousseau. Trad. Erlon José Paschoal e Jézio Gutierre. São Paulo: Unesp, 1999.

DENT, N. J. H. Dicionário Rousseau. Trad. Álvaro Cabral. Rio de Janeiro: Zahar, 1996.

DERATHÉ, Robert. Jean-Jacques Rousseau e a ciência politica de seu tempo. Trad. Natalia Maruyama. São Paulo: Editora Barcarolla; Discurso Editorial, 2009.

FORTES, Luís Roberto Salinas. Rousseau: da teoria à prática. São Paulo: Ática, 1976.

GRAMSCI, Antonio. Cadernos do cárcere. Trad. Carlos Nelson Coutinho. 2. ed. Rio de Janeiro: Civilização Brasileira, 2001. Vol. 2.

30 Tendo em vista que "se sobrassem aos particulares alguns direitos dos quais pudessem usufruir sem a permissão do soberano, a vontade geral deveria inclinar-se diante das vontades particulares ou, ao menos, medir-se com elas; ela deixaria de lhes ser superior e de lhes impor sua lei. Deixar-se-ia, assim, subsistir a oposição das vontades particulares que se propunha precisamente suprimir" (DERATHÉ, 2009, p. 339). 
Escritos politicos. Trad. Manuel Simões. Col. Universidade Livre. Lisboa: Seara Nova, 1976. Vol. I.

HEGEL, Georg Wilhelm Friedrich. Princípios da filosofia do direito. Trad. Orlando Vitorino. São Paulo: Martins Fontes, 1997. (Col. clássicos).

KOSIK, Karel. Dialética do concreto. Trad. Célia Neves e Alderico Toríbio. 2. ed. Rio de Janeiro: Paz e Terra, 1976.

LAPASSADE, Georges. Grupos, organizações e instituiçōes. Trad. Henrique Augusto de Araújo Mesquita. 3. ed. Rio de Janeiro: Francisco Alves, 1989.

LEFEBVRE, Henri. Lógica formal/lógica dialética. Trad. Carlos Nelson Coutinho. 5. ed. Rio de Janeiro: Civilização Brasileira, 1991.

LOURAU, René. A análise institucional. Trad. Mariano Ferreira. 2. ed. Petrópolis: Vozes, 1996.

LUKÁCS, Georg. Introdução a uma estética marxista: sobre a categoria da particularidade. Trad. Carlos Nelson Coutinho e Leandro Konder. Rio de Janeiro: Civilização Brasileira, 1978. Vol. 33/Série Estética. (Col. perspectivas do homem).

MARX, Karl. Critica da filosofia do direito de Hegel. Trad. Rubens Enderle e Leonardo de Deus. 2. ed. revista. São Paulo: Boitempo, 2010.

POUlantZAS, Nicos. Poder político e classes sociais. Trad. Francisco Silva. São Paulo: Martins Fontes, 1977.

PROUDHON, Pierre Joseph. O que é a propriedade? Trad. Marília Caeiro. 2. ed. Lisboa: Editorial Estampa, 1975.

ROUSSEAU, Jean-Jacques. Do contrato social. Trad. Lourdes Santos Machado. São Paulo: Nova Cultural, 1999. Vol. I.

VITA, Álvaro de. Vontade coletiva e pluralidade: uma convivência possível? Lua Nova, São Paulo, n. 23, p. 211-231, mar. 1991.

Recebido em: 1\%/9/2016

Revisões requeridas em: 13/10/2016

Aceito em: 25/10/2016 